\title{
The feasibility of developing new automotive parts from the supplier perspective: proposal of a managerial tool for a plastics company
}

\author{
Raoni Barros Bagno, Ana Luiza Rodrigues da Silveira ${ }^{b}$ Renato Soares Leite ${ }^{b}$ \\ aProduction Engineering Department, Technology Center for Quality and Innovation, Engineering School, Universidade Federal de Minas Gerais \\ bProduction Engineering Department, Polytechnic School, Pontifíicia Universidade Católica de Minas Gerais \\ e-mails: rbagno@dep.ufmg.br; analuiza.r.s@hotmail.com; eng.renatoleit@@gmail.com
}

\begin{abstract}
The automotive sector is one of the main pillars of the Brazilian industry and supplier companies - although often neglected in the literature - have a crucial role in its growth. In these companies, processes associated with product development have increasing importance due to shorter products' life cycles and the continuous spillover of R\&D activities to emergent countries, as observed in last decades. This study aims at proposing a managerial tool to support the business process of a plastics company, focused on activities triggered by the Request For Quotation (RFQ of "buy" non-Codesign parts, often sent by a car manufacturer) till the formal response to the client and the project planning. To achieve this objective, a search on the product development literature nurtured the contours of a first version of the proposal. Then, data about the quotation processes of two other automotive suppliers was collected in order to allow a comparative study. Finally, structured interviews were conducted with some managers of the plastics company to refine the understanding about the information flow and generate a final version of the proposed process and tool. As a result, a new process was designed as so as a new managerial tool to support its systematic application within the company. Such a proposal intends to guide the assignment of responsibilities among the functional areas, define clear inputs and outputs for each task and also assure that precise information can be generated for each involved agent throughout the quotation process and project planning. As a conclusion, not just the risk associated with the quotation process is expected to reduce, but also the horizontal communication and reliance among all internal functions involved is expected to improve. The experience described in this study also intends to serve as a reference for other non-codesign supplier companies in their challenge of establishing processes that enable a better insertion in the automotive supply chain and in its inter-organizational product development processes.
\end{abstract}

Keywords: feasibility analysis, product development, automotive industry.

\section{Introduction}

The automotive sector has become one of the world's main economic pillars in the last century and its supply chain is highly internationalized, mainly when compared to other important industries throughout the world (AGÊNCIA..., 2009). Considering this context as a starting point, the present study focuses on the intermediary links of such a chain - the suppliers - analyzing their organizational processes associated with their participation and contribution with carmakers' product development systems. For the economic strategy of a specific country, fostering the organizational development of companies that are directly connected to the automotive chain is an important alternative to attract technology-based activities related to several disciplines, which ultimately help to accelerate the dynamics of many other industry sectors (DIAS et al., 2011).
As a rule, a carmaker selects its suppliers in product development phases through a process of sourcing. Such a process is recurrent for all "buy" parts and is marked by the definition of product's technical specifications, production volumes, prices, quality requirements and other points, that subsequently turn into contractual topics. Then, all the subjacent activities associated with this sourcing process - and especially those assigned to the supplier companies - get strong relevance to assure lower levels of risk and uncertainty not just along the next product development phases, but also to the production.

This study is focused on the feasibility analysis that is performed by a supplier company after receiving a Request For Quotation (RFQ) from a carmaker, interested in outsourcing one or a set of components that will be applied in a new car model, at this time, under development. 
The study's outcome is the proposition of a business process and an associated managerial tool, intended to support the decision making in the supplier company (the formal response to RFQ) and providing guidance to the whole set of functional activities performed to analyze the technical-economic feasibility of manufacturing and supplying these new parts.

\section{Theoretical background}

\subsection{New product development and feasibility analysis}

The Rozenfeld et al. (2006) approach to the new product development emphasizes the need for strong alignment between pre-development activities and the project plan. The authors also highlight the importance of defining costs, development times and some other guidelines early in the project - even considering the effects that uncertainties can impose to these definitions at this time in terms of accuracy. It may be called a pre-model of estimations that come from the research and other preliminary efforts. Therefore, the project planning faces special challenges when mapping the project activities as detailed as possible to allow the identification and integration of resources needed to achieve the desired results.

Grieves (2006 apud VALAMBRINI, 2008) argues that the product lifecycle management allows the evaluation of its dimensions in a certain industry. Figure 1 synthesizes the proposal of this author, also highlighting the specific moment of the product lifecycle that matters most to our study. The technical responsibility at this point

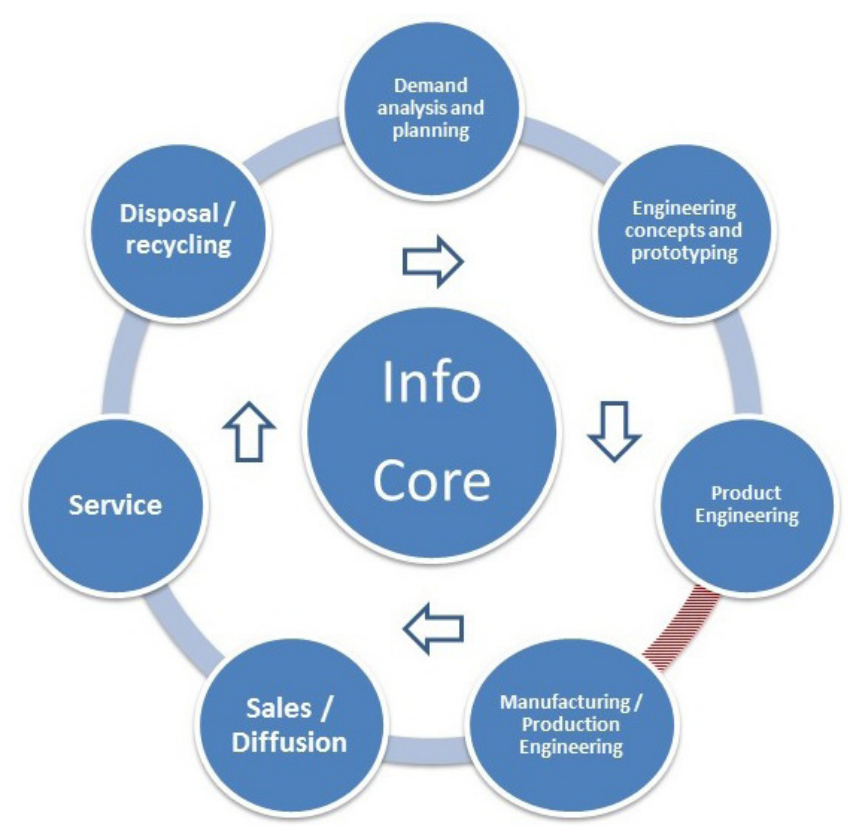

Figure 1. The product lifecycle management. Adapted from Grieves (2006 apud VALAMBRINI, 2008). moves from Product Engineering to Manufacturing and Production teams. This is the last moment to decide which parts should be done "at home" (make) and which ones should be outsourced (buy) to supplier companies. This is also the point of the process when the carmaker turns available engineering drawings for non-codesign parts and starts searching for suppliers interested in developing the respective manufacturing processes and logistic arrangements to make the parts available for commercial production and ready for the launching date.

Non-codesign suppliers are not requested to contribute to the product design (although it may occur, often due to manufacturing constraints) (GURGEL, 2009). Nonetheless, responsibilities concerning manufacturing processes, logistics arrangements, the assurance that finished parts meet the technical specifications and other issues related to quality and cost management are normally assigned to these companies.

According to Woiler and Franco (2008), a project can be subdivided in subprojects, viz, Feasibility Project, Final Project and Financial Project. The feasibility project is the first step and its mission is to check the general feasibility of executing the project. When triggering a sourcing process, the purchasing department of a carmaker normally makes the first contacts with suppliers already recognized by their competence in manufacturing such kind of component or similar ones. Then, an RFQ is sent to them and so, important information (e.g., engineering drawings, predicted production volumes, target costs and general quality requirements) becomes available to those suppliers which, in turn, must prepare their formal responses. On the supplier side, analyzing this information adequately is crucial to translate it into project requirements and to calculate the investments, resources and time needed to execute the project. When compared to the client expectations and the internal strategy, all this effort converges in an understanding about the project feasibility to the company, if it beats its competitors in the sourcing race.

Following the approach of Woiler and Franco (2008), the Final Project is built upon an information set required for the execution and includes critical parameters such as process, basic equipment needed, schedule, etc. The Financial Project gathers information concerning material/equipment costs and all other investments required to achieve the project's basic requirements.

One of the main decisions taken at the beginning of a new product development - just after the supplier receives the RFQ - regards the team that will conduct the analysis and, if the proposal gets approved, take central responsibilities in the project execution. Rozenfeld et al. (2006) recommend identifying the project stakeholders paying close attention to the responsibilities to be assigned to each one throughout the project. At this point, not just the responsibilities, but also 
the limitations, needs for support, kind of involvement and other issues must guide the selection of people to integrate the team (Figure 2). There is a remarkable importance when identifying the project stakeholders to consider their integration and evaluation of the extent in which they represent different functional areas of the company involved in the challenge of product development, manufacturing and distribution. Therefore, a communication plan can be delineated, assuring that information generated by each person in each activity performed is clear and aligned with the entire team, which also avoids unexpected stops and reworks in later stages (PROJECT..., 2004).

\subsection{Business process management}

According to Davenport (1993), the proposition of improvements in any business process demands deep and previous knowledge of the current one. Otherwise, the whole process structure may suffer with misalignments among the people involved. This author proposes a model for the study of a business process that is divided into six steps (key-tasks - Figure 3).

Another important issue to be considered when working on improvements in current processes is to keep the same evaluation criteria for both current and proposed processes.
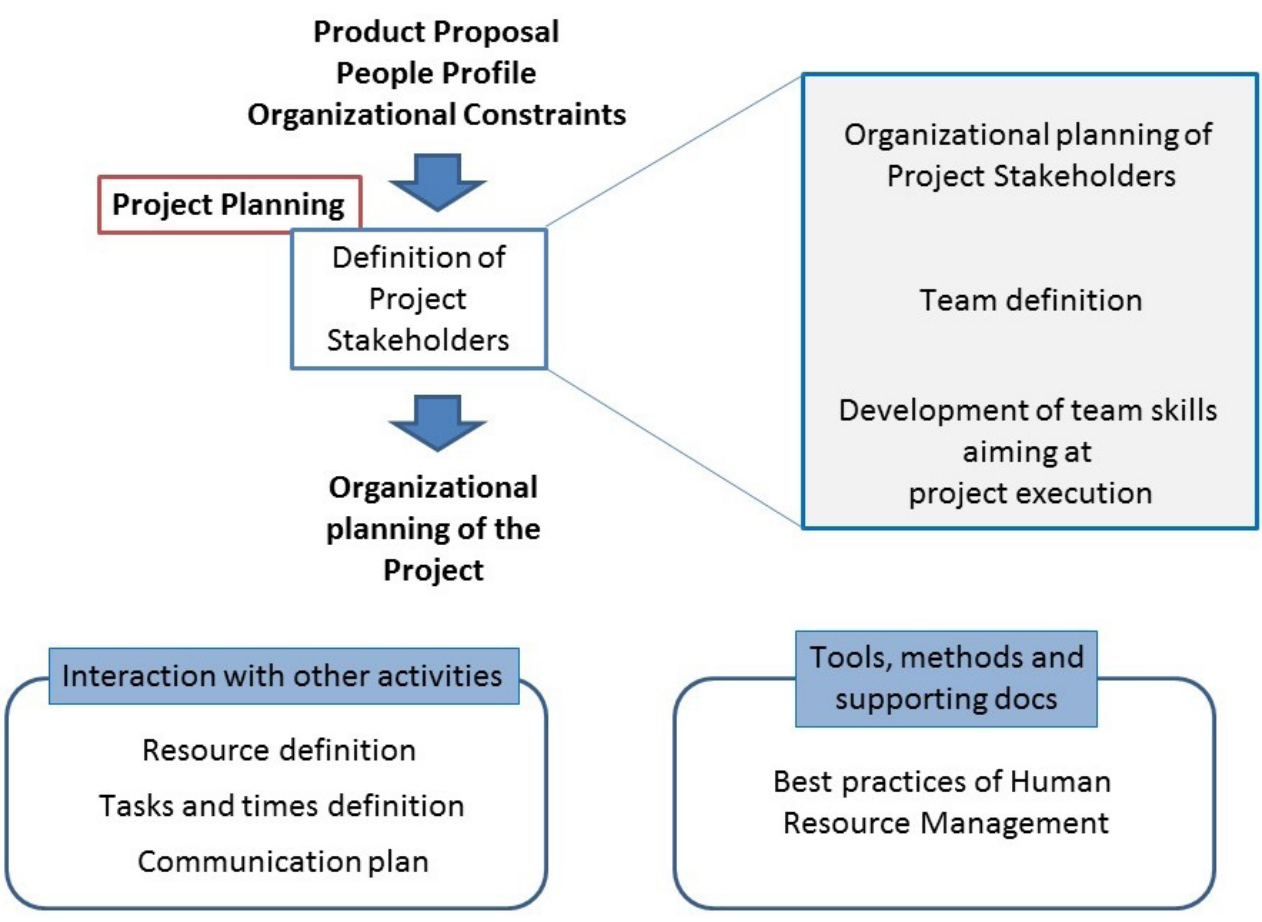

Figure 2. The definition of Project Stakeholders. Adapted from Rozenfeld et al. (2006, p. 155).

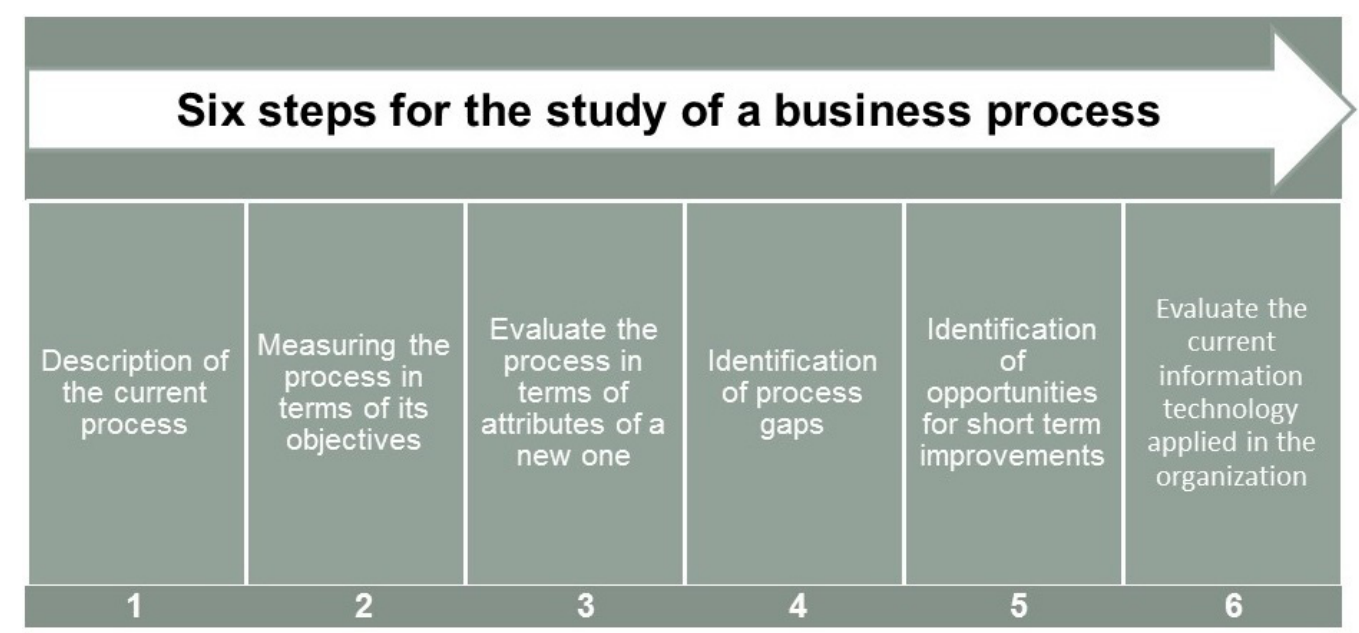

Figure 3. Six steps for the study of a business process. Adapted from Davenport (1993). 
It assures that the nature of process outputs is maintained whilst improvement efforts are made. Davenport (1993) also argues that changes made over a business process must result in shorter times to perform the process and better quality of its outcomes. Such criteria must be always the central concern in proposing any kind of analysis and improvement.

\section{Methodology}

This study aimed at building a business process and a supportive tool to guide the feasibility analysis of developing and manufacturing new automotive parts from the perspective of the supplier company. The main outcome of such a process is the formal response of a car manufacturer's RFQ. For this purpose, a specific company was selected in the field of plastics industry to which the process and respective tool were then designed and proposed for implementation. This company is here referred as CPNY01.

Applying participative observation as the main research instrument, the authors mapped the practices and informal activities taken by the CPNY01 in order to propose an initial version of a process - to be later lapidated in the next phases of the study. The second step is characterized by a benchmarking study with two other companies (here referred as CPNY02 and CPNY03) using focused non-structured interviews. Important to say that these companies have in common with CPNY01 the role in the supply chain - non-codesign suppliers of automotive parts - but they were selected from other manufacture expertise fields in order to avoid data collection problems from direct competitors of CPNY01. In what regards the research approach, according to Barros and Lehfeld (2000, p. 91), non-structured focused interviews are based on a flexible script, designed to allow the collection of data related to several topics tangential to the central subject. Such topics can emerge whilst the interview is conducted and the interviewer must have the skill to quickly identify if the topic represents a good opportunity to be more explored (and so collect more data on it) or, if not, move to a planned question. Intermediary versions of the final proposal were generated and discussed among the authors in light of new data collected from CPNY02 and CPNY03 and of their (now mapped) practices took for RFQ responses. After this step, efforts were made again on CPNY01, where semi structured interviews were conducted with the main process stakeholders in diverse functional areas to help converging all the knowledge generated into a realistic proposal to deal with the central problem posed and to be implemented in CPNY01 as a pilot initiative.

This research is essentially qualitative due to the very nature of the problem, data collected for analysis and the intended form of presenting the outcomes. Moreover, an interventionist intention marks these outcomes, viz, a business process and a supportive managerial tool, once they are conceived aimed at real implementation on CPNY01. The implementation phase, however, exceeds the scope of the present paper and this decision was motivated by two points: first, a detailed approach of the CPNY01 experience in implementing and operating the new tool and business processes would require an extensive effort of participant observation combined with a regular flow of RFQ related to distinct products. Second, there is no definitive version of any tool or process, since the efforts made in adjusting them for better efficiency and results are ongoing tasks with no end in dynamic environments. Under this perspective, the present paper intends to elucidate forms to deal with problems and to organize the work needed to design assertive proposals, serving as a reference to other similar challenges.

According to Vieira (2009), a qualitative study analyzes and consolidates information regarding habits and opinions of the interviewees. Thus, the evidences that guide this research come from direct observation in CPNY01, interviews in CPNY02 and CPNY03 and, finally, interviews in CPNY01.

\section{Field study}

\subsection{Mapping current practices into business processes}

Figure 4 shows the practices in CPNY01, 02 and 03 for the quotation of new automotive parts, emphasizing the functional areas involved. For the interviewed people of CPNY02, the main concerns in preparing a response for a RQF were: (i) the lack of communication among the areas involved; (ii) limitations of the information shared by the program manager, often limited to immediate questions to be solved; (iii) the lack of a formalized process to avoid the disregard of important issues, what makes the response inaccurate and risks the future of the business; and (iv) poor definition of the responsibilities assigned to each person or even functional area represented in the flow. Such problems often resulted in inappropriate development plans that did not consider an important validation test, or led to manufacturing decisions that caused excessive wastes in production or even represented the beginning of a new era of several conflicting relations with the client. By turn, in CPNY03, the major perceived problems were the information flows and their subsequent consequences in delaying the whole process. Another point was the use of poor technical documentation, rarely containing information enough to support an accurate feasibility analysis or a good financial sheet. These points also led to the disregard of essential points, causing constant rework in revising the formal response. 


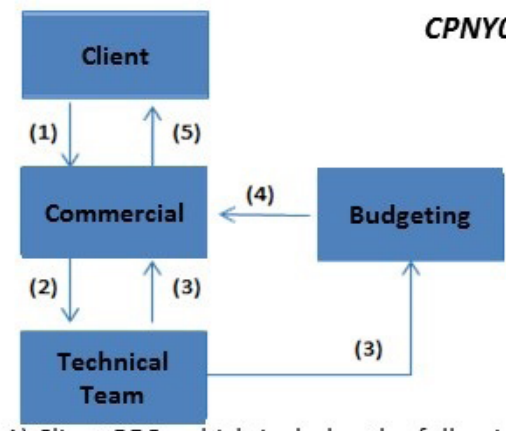

1) Client RFQ, which includes the following docs.: vehicle description, versions, market demand, project schedule, drawings and norms.

2) The commercial area diffuses the information and organizes the kick-off meeting to start the feasibility analysis.

3) The technical team lists the main project requisites and defines the tasks and times of project plan, in respect to client's deadlines.

4) The analysis is forwarded to budgeting and commercial teams.

5) The commercial team elaborates the formal response to $R F Q$, including the technical issues and the necessary investments.

Functional areas: commercial, budgeting, product engineer, process engineer sub areas (tooling, assembly, painting, control devices, etc.), quality, materials lab and logistics.

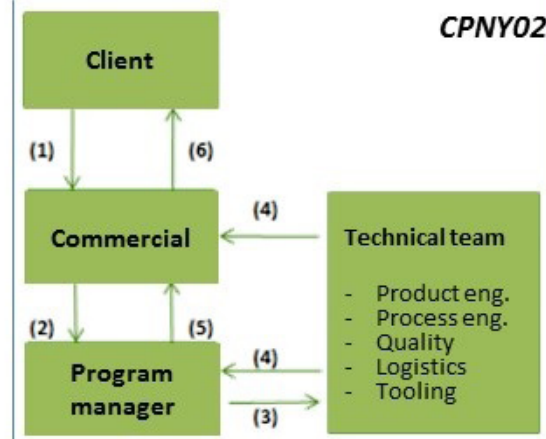

1) Client RFQ, as in CPNY01.

2) Commercial area centralizes information on the Program Manager.

3) Program manager pre-analyses and calls up the technical team.

4) After analyzing the docs, the technical team lists the main project requirements and activities. Thus, all the information is sent back to program manager and commercial area.

5) The program manager checks the information and make the last analysis with the commercial area to validate all the contents.

6) The commercial area finalizes the necessary quotations and prepares the formal response to the client.

Functional areas: commercial, Product eng., process eng., tooling, quality and logistics.

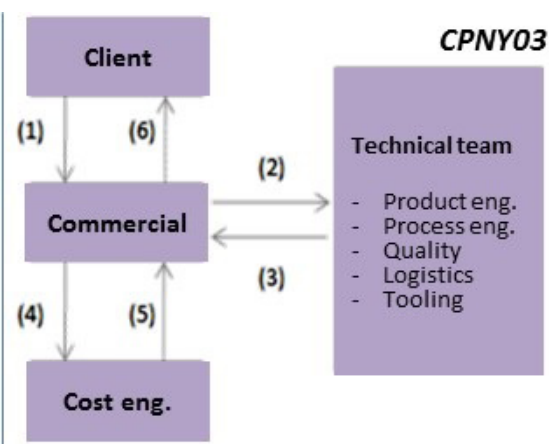

1) Client RFQ, as in CPNY01;

2) Commercial area makes the docs available to technical team and cost eng.; 3) The technical team analyzes the docs, and defines the scope of budgeting and project activities. The technical team send the information to the commercial area, which, in turn, checks all the information. 4) The commercial area shares the information with cost engineering team. 5) The cost engineering team defines targets for investments in tooling and for product costs.

6) Commercial area concludes the feasibility analysis and prepares the formal response to the client.

Functional areas: "Technical teams" in a generic form. Communication is made through informal and non-regular meetings.

Figure 4. Management flows for the quotation of new automotive parts. Source: The authors.

\subsection{The proposal of a business process and a management tool for CPNYO1}

The analysis of the information collected in each company guided the proposition of a new business process for CPNY01, based on improvements made over the previous one. Attached to this new process, a managerial tool was then proposed in order to support the conduction of the activities listed and the definition of how each functional area relates to the activities, whether acting as owner or other possible forms of influencing what is done. This tool is divided in nine different items (or information sets), that were considered the most important for feasibility analysis. For practical purposes, the tool is illustrated in Table 1 by a partial representation of its main constitutive elements. The following topics give more details of the tool's general scope and use.

a) General program's input data (21 items) - information considered essential for the start and for the conduction of the whole process in the supplier company: key dates, the availability of $2 \mathrm{~d}$ and $3 \mathrm{~d}$ drawings of the automotive parts in analysis, intended production volumes, product life cycle, etc. Normally, this kind of information must be put available in clear form by the client company. Thus, the companies that compete with each other along the sourcing process can better plan their internal activities. If part of this information is not available, the supplier must evaluate the risks and uncertainties derived from this lack of data, alerting the client company about it and registering the implications in its own response.

b) Product Planning ( 8 items): issues related to technology (to which extent it is adherent to the company's previous experience). This set helps to understand some key uncertainties that the development of this new part could bring to a project. When carefully evaluating technological uncertainties represented by the product materials, geometry, tolerances and other aspects, special 
Table 1. Managerial tool proposed to guide the operation of a new process for feasibility analysis.

\begin{tabular}{|c|c|c|c|c|c|c|}
\hline \multicolumn{7}{|c|}{ FEASIBILITY OF DEVELOPING NEW AUTOMOTIVE PARTS } \\
\hline \multirow{2}{*}{\multicolumn{3}{|c|}{$\begin{array}{l}\text { PROJECT/PROGRAM: } \\
\text { OWNER: }\end{array}$}} & \multirow{2}{*}{\multicolumn{2}{|c|}{\begin{tabular}{|l|} 
RFQ arrival date: \\
RESPONSE DEADLINE:
\end{tabular}}} & \multirow{3}{*}{$\begin{array}{l}\text { CPNY01 } \\
\text { OWNER }\end{array}$} & \multirow{3}{*}{$\begin{array}{l}\text { Version: } 1.0 \\
\text { DEADLINE }\end{array}$} \\
\hline & & & & & & \\
\hline ITEM & INPUTS & $\mathbf{Y}$ & $\mathbf{N}$ & $\begin{array}{c}\text { OUTPUT } \\
\text { INFORMATION / } \\
\text { ACTIONS }\end{array}$ & & \\
\hline 1 & \multicolumn{6}{|l|}{ GENERAL PROGRAM'S INPUT DATA } \\
\hline 1.1 & Project & & & & & \\
\hline 1.2 & Product description & & & & & \\
\hline 1.3 & Vehicle models ans versions & & & & & \\
\hline 1.4 & Product lifecycle & & & & & \\
\hline 1.5 & Total predicted production volumes & & & & & \\
\hline 1.6 & Production volumes for field service & & & & & \\
\hline 1.7 & Production volumes for foreign market & & & & & \\
\hline 1.8 & Project Deadlines & & & & & \\
\hline 1.9 & Prototype scheduling & & & & & \\
\hline 1.10 & Parts for process validation (qts, timing) & & & & & \\
\hline 1.11 & Pre-serie (qts, timing) & & & & & \\
\hline 1.12 & SOP (timing, curves) & & & & & \\
\hline 1.13 & 2d Drawings & & & & & \\
\hline 1.14 & Process control plan availability & & & & & \\
\hline 1.15 & Specs and norms & & & & & \\
\hline 1.16 & 3d Drawings & & & & & \\
\hline 1.17 & Eng. Changes & & & & & \\
\hline 1.18 & $\begin{array}{l}\text { Information about collor, textures, } \\
\text { painting specs, special marks, etc. }\end{array}$ & & & & & \\
\hline 1.19 & $\begin{array}{l}\text { Interface definitions with other parts and } \\
\text { sub-systems }\end{array}$ & & & & & \\
\hline 1.20 & People previous knowledge and skills & & & & & \\
\hline 1.21 & $\begin{array}{l}\text { Information about target costs, quality, } \\
\text { production efficiency, relyablity, etc. }\end{array}$ & & & & & \\
\hline 2 & & DUC & PLAN & ING - Product Engineerin & & \\
\hline 2.1 & $\begin{array}{l}\text { Technological newness for the } \\
\text { organization, considering raw materials, } \\
\text { coatings, textures, geometries and other } \\
\text { aspects. }\end{array}$ & & & & & \\
\hline 2.2 & $\begin{array}{l}\text { Responsibility assignments of the whole } \\
\text { system, subsystem and other components. } \\
\text { Codesign assignments and carmaker's } \\
\text { network management policy. }\end{array}$ & & & & & \\
\hline 2.3 & $\begin{array}{l}\text { Presence (current or predicted) of the same } \\
\text { car model in other manufacturing sites. }\end{array}$ & & & & & \\
\hline 2.4 & $\begin{array}{l}\text { Definition of key product characteristics } \\
\text { which could demand special process } \\
\text { controls. }\end{array}$ & & & 2D Drawings checked & & \\
\hline 2.5 & $\begin{array}{l}\text { Identification of new key product } \\
\text { characteristics }\end{array}$ & & & & & \\
\hline 2.6 & Special norms or legislation to consider & & & & & \\
\hline 2.7 & $\begin{array}{l}\text { Impacts of above items on component } \\
\text { costs or program investments. }\end{array}$ & & & Bill of Materials (BOM) & & \\
\hline 2.8 & $\begin{array}{l}\text { Other engineering expenses to consider } \\
\text { (e.g. travel costs, special communication } \\
\text { needs) }\end{array}$ & & & Project scope & & \\
\hline 3 & GENERAL PROCESS PLANNING - P & & gineer & & & \\
\hline
\end{tabular}

Source: The authors. 
Table 1. Continued...

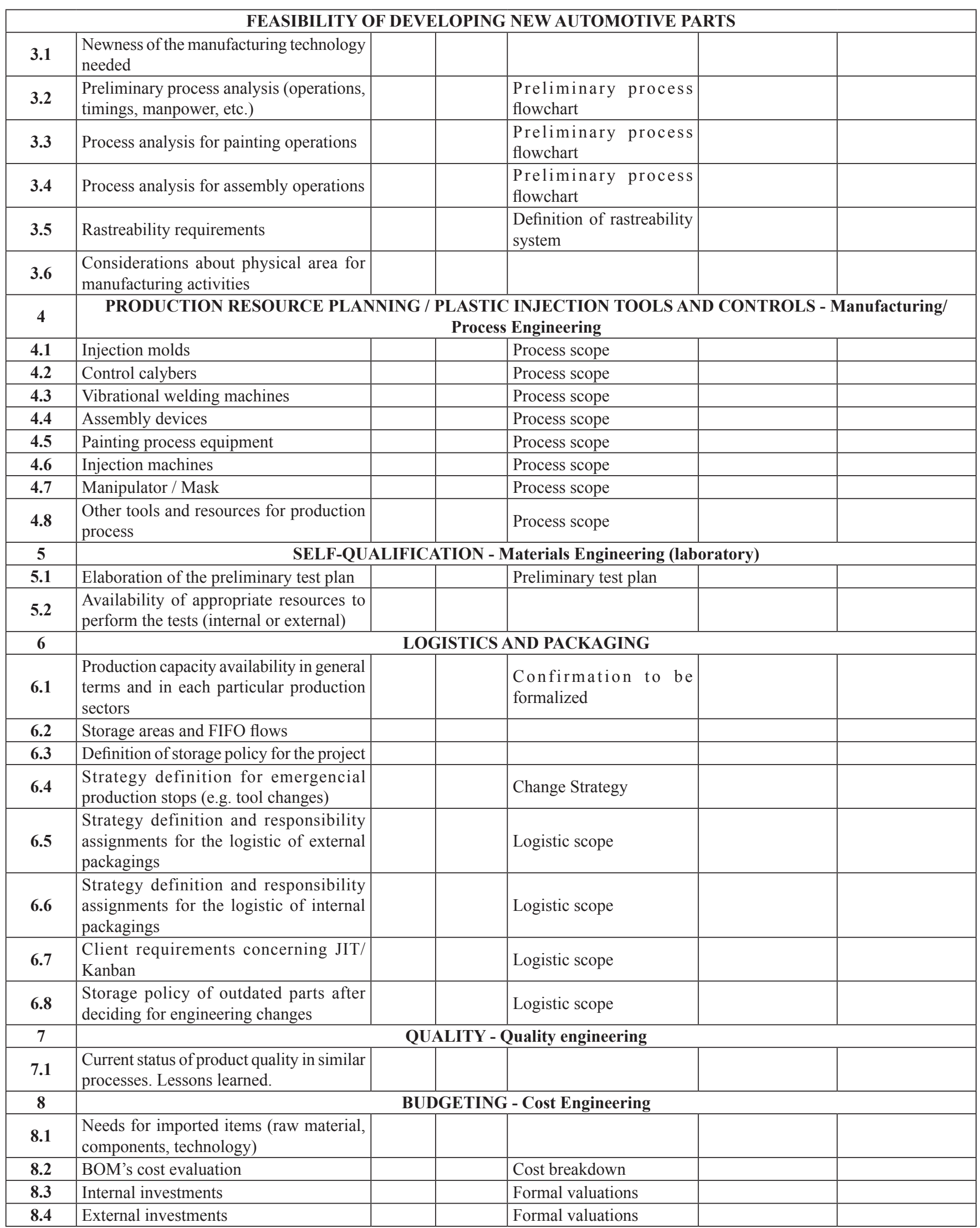

Source: The authors. 
Table 1. Continued..

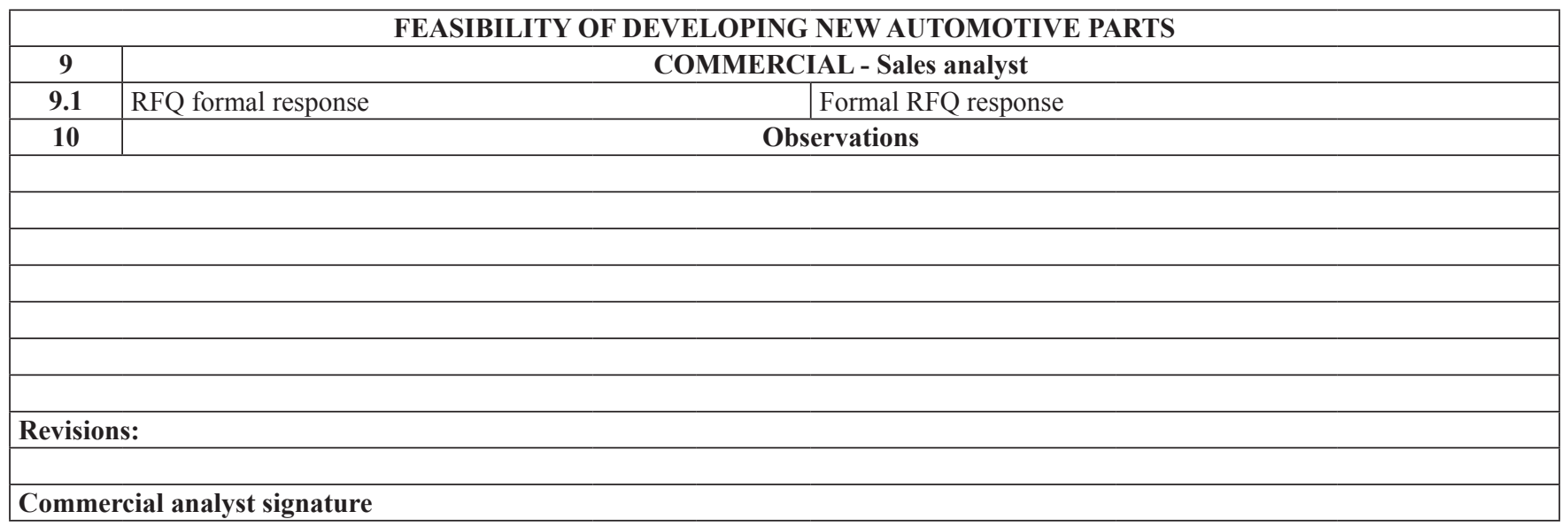

Source: The authors.

considerations should be made on the planned budget of a new manufacturing tool or even other changes in terms of plant layout or even metrological devices, among other examples. The possibility of a new legislation requirement or the exigence to considerate specific product parameters as key characteristics should also be considered in these fields.

c) General Process Planning (6 items) - Here, information regarding the manufacturing resources is discussed. The need of new machinery, new room for stock or preassembly operations, the implications of different products living together in the same lines or flow changes in internal logistics are some of the questions raised in these fields.

d) Production resource planning / plastic injection tools and controls (8 items) - Detailed process planning, tools and their adjustments, reliability issues, means to measure and control the production operations, etc.

e) Self-qualification (2 items) - the focus here is on issues such as the availability of a test plan or the adequacy of internal devices to perform these tests as required by client norms. Some alternatives could also be evaluated at this point, e.g., the outsourcing of tests or the negotiation of responsibilities regarding some tests with the client company or even the reanalysis of some test parameters regarding its conduction or requirements for approval.

f) Logistics and Packaging (8 items) - Strategies to respond to the client's orders after the product launch: which logistics systems should be considered (Just in Time, Electronic Kanbans, etc.), the level required for safety stocks, exigencies regarding parts protection and transportation, the need for recirculating special packages, among others. g) Quality (2 Items) - Quality specifications and requirements for ongoing production.

h) Budgeting (4 items) - This set is very transversal since it results from analysis of previous fields. Here, all the necessary investments to put the factory ready for production must be considered and discussed.

i) Commercial ( 1 item) - This field closes the process and culminates with the formalization of a response to the RFQ.

According to the people from CPNY01 involved in the process who, at the moment we were preparing the first revision of this paper, were applying the proposal for new RFQ responses, the main perceived advantages could be cited: (i) more assertive analyzes could made over complex products (in terms of production process and organization); (ii) better communication and assignments of tasks in kick-off meetings; (iii) improved practices regarding the documentation of activities conducted throughout the process, which facilitates the search for information even after sending formal responses; (iv) less delays in general; (v) opportunities for improving the general work are identified and implemented faster; and (vi) documents and information cited in "output/actions" column serve as evidences for client or even external audits. Notwithstanding, there was a certain fear that the processes - first considered simple and informal - become rigid and bureaucratic. In regard to such consideration, scalable versions of both process and tool could fit to different levels of the complexity represented by the overall challenge.

For the future, CPNY01 team expected to, starting from this first version of a implementable proposal, continuously improve the feasibility analysis process aiming at more assertiveness and time reductions in sending formal responses to new RFQs. More than that, there was a common perception that the organization were able to assume more 
participative roles in product development which, in some extent, can favor the relationship with client companies and attract business opportunities. The team has also scheduled an annual meeting to discuss the experiences in performing the process and identify opportunities to improve the work.

\section{Final remarks}

For CPNY01, this experience could identify important opportunities to improve the quality of the information generated and shared by each functional area in building a formal response to a client RFQ. The proposal that results from this study offers a path to face problems such as incomplete information, unshared deadlines and lacks of general work organization. Thus, we can consider that the objectives posed in this research were achieved. To best fit with Davenport's (1993) recommendations for business process analysis, a complementary study could focus on establishing metrics (e.g. average time to send formal responses, percentage of tool's fields filled on time, etc.). Such metrics could allow comparisons among different RFQs, clients or even teams involved in the challenge and help to improve the way the process is managed and problems are identified.

The managerial tool that results from this research effort can serve as a reference to other companies involved in the typical challenges of supplying "buy" non-codesign components for automotive industry or similar industrial environments. Co-design supplier can also benefit from this experience since the differences in context and information flows are respected. Finally, by focusing on the internal challenges of non-codesign part suppliers, this study contributes to make these internal links of supply chain stronger. Other studies could adapt the current proposal to other contexts and production environments or even to service companies, sharing results and learning points.

\section{References}

AGÊNCIA BRASILEIRA DE DESENVOLVIMENTO INDUSTRIAL - ABDI. Estudo prospectivo setorial automotivo. Brasília, 2009. Available from: <www.abdi. com.br/Estudo/Automotivo.pdf>. Access in: 10 Dez 2014.

BARROS, A. J. P.; LEHFELD, N. A. S. Fundamentos de metodologia. 2. ed. São Paulo: Makron Brooks, 2000.

DAVENPORT, T. H. Reengenharia de processos: como inovar na empresa através da tecnologia da informação. Rio de Janeiro: Ed. Campus, 1993.

DIAS, A. V. C. et al. Recent evolutions in R\&D activities in the Brazilian automotive industry. In: INTERNATIONAL GERPISA COLLOQUIUM, 19., 2011, Paris. Proceedings... Paris: GERPISA, 2011.

GRIEVES, M. Product lifecycle management: driving the next generation of lean thinking. New York: McGraw-Hill, 2006 .

GURGEL, F. A. Glossário de Engenharia Industrial. 20. ed. São Paulo: Fundação para o Desenvolvimento Tecnológico da Engenharia, 2009.

PROJECT MANAGEMENT INSTITUTE - PMI. Guia PMBOK®. 3. ed. Filadélfia: PMI, 2004.

ROZENFELD, H. et al. Gestão de desenvolvimento de produtos: uma referência para a melhoria do processo. São Paulo: Saraiva, 2006. 542 p.

VALAMBRINI, A. C. O processo de produção na empresa montadora sob a perspectiva informacional da gestão do ciclo de vida do produto (PLM). In: ENCONTRO NACIONAL DE ENGENHARIA DE PRODUÇÃO, 28.,13-16 Out., Rio de Janeiro. Anais... Rio de Janeiro: ABEPRO, 2008.

VIEIRA, S. Como elaborar questionários. São Paulo: Atlas, 2009.

WOILER, S.; FRANCO, W. Projetos: planejamento elaboração e análise. 2. ed. São Paulo: Atlas, 2008. 